Sains Malaysiana 49(3)(2020): 537-544

http://dx.doi.org/10.17576/jsm-2020-4903-08

\title{
Computational Quest for Finding Potential Ebola VP40 Inhibitors: A Molecular Docking Study
}

(Pencarian Pengiraan untuk Mencari Potensi Perencat Ebola VP40: Suatu Kajian Mengedok Molekul)

\author{
Mohamad Ariff Mohamad Yussoff, Azzmer Azzar Abd Hamid, Shafida Abd Hamid \& \\ KHAIRUL BARIYYAH ABD HALIM*
}

\begin{abstract}
Interaction of Ebola virus matrix protein VP40 with RNA is crucial in the early infection stage to facilitate the transcription of the viral gene. Thus, VP40 is a promising target to inhibit the Ebola virus from spreading. This study aims to identify and optimize ligands that can potentially block the VP40-RNA binding site. A total of 42 compounds from previously studied ligands from the literature were simulated against the RNA binding site using Autodock Vina. The top ten ligands were used as templates for similarity search in ZINC database followed by structured-based virtual screening. Then, the ADME properties of the top compounds were predicted computationally using SwissADME server. Our results showed that Q-96 (ZINC ID: 1338855) is the best docked compound with binding free energy of -7.5 kcal/ mol. The compound also has satisfactory ADME properties prediction with good lipophilicity value, moderate water solubility and high gastrointestinal absorption. Besides, this ligand does not violate any drug likeness rules as well as no PAINS and Brenk alerts, indicate it has the properties as a drug. Thus, it is worth to carry out further investigations on this structure more in silico as well as in vitro and in vivo levels towards finding the treatment for Ebola virus disease.
\end{abstract}

Keywords: ADME; Ebola virus; molecular docking: VP40 matrix protein

ABSTRAK

Interaksi matriks virus Ebola VP40 dengan RNA adalah penting dalam peringkat jangkitan awal untuk memudahkan transkripsi gen virus. Oleh itu, VP40 adalah sasaran yang sesuai bagi menghalang virus Ebola daripada terus merebak. Kajian ini bertujuan untuk mengenal pasti dan mengoptimumkan ligan yang berpotensi menghalang tapak pengikat VP40-RNA. Sejumlah 42 sebatian daripada kajian terdahulu telah disimulasi di tapak pengikat RNA menggunakan Autodock Vina. Sepuluh ligan terbaik telah dipilih sebagai templat pencarian persamaan dalam pangkalan data ZINC diikuti oleh penyaringan maya berasaskan struktur. Ciri-ciri ADME sebatian telah diramalkan secara komputasi menggunakan pelayan SwissADME. Keputusan kajian kami menunjukkan bahawa Q-96 (ZINC ID: 1338855) adalah sebatian terbaik dengan tenaga bebas pengikat $-7.5 \mathrm{kcal} / \mathrm{mol}$. Sebatian ini juga menunjukkan sifat ADME yang memuaskan dengan nilai kelipofilikan yang baik, kelarutan air secara sederhana dan penyerapan gastrousus yang tinggi. Selain itu, ligan ini tidak melanggar sebarang hukum persamaan drug juga tidak memberi sebarang amaran PAINS dan Brenk, menjustifikasikan ia mempunyai ciri-ciri sebagai drug. Oleh itu, adalah wajar untuk menjalankan kajian lanjutan yang lebih dalam mengenai struktur ini secara in silico, in vitro dan in vivo ke arah pencarian rawatan terhadap penyakit virus Ebola.

Kata kunci: ADME; cantuman molekul; protein matriks VP40; virus Ebola

\section{INTRODUCTION}

Ebola Virus (EBOV) is a lipid-enveloped filamentous virus that leads to the Ebola virus disease (EVD) which is formerly known as Ebola hemorrhagic fever, a severe disease that was first appeared in 1976 in two concurrent outbreaks; one was in Nzara, South Sudan and the other one was in Yambuku, Democratic Republic of Congo. The virus was transmitted to people from wild animals and then spread to the human population through human-to-human transmission with a fatality rate up to $90 \%$ (Feldmann \& Geisbert 2011). It has been suggested that the virus resides in fruit bats of Pteropodidae family as its natural host
(WHO | Ebola virus disease 2017). The 2014-2016 Ebola outbreak in West Africa was known as the largest and most complex Ebola outbreak. During that time, EVD had spread between countries including Liberia, Nigeria and the USA (WHO | Ebola virus disease 2017). In August 2018, an EVD outbreak was declared by the Ministry of Health of the Democratic Republic of the Congo that took place in North Kivu Province. By June 2019, more than 2000 cases were confirmed with 1506 deaths (WHO | Ebola situation reports: Democratic Republic of the Congo 2019).

EBOV harbours a negative-sense single-stranded RNA (ssRNA) genome with the length of $19 \mathrm{~kb}$ that encodes 
seven proteins namely nucleoprotein, VP30, VP35, L-polymerase (L) protein, VP24, transmembrane glycoprotein (GP) and VP40. Each of these encoded proteins plays different functions throughout the Ebola virus life cycle. Transmembrane GP is the only protein on the surface of the virion and accounted for the entry of the virion into the host cells (Martin et al. 2016). Meanwhile, $\mathrm{L}$ protein which is an RNA-dependent RNA polymerase ( RdRp) involves in viral genome transcription and translation by forming the RdRp complex together with VP30 (Martin et al. 2017). VP24 and VP35 are involved in inhibition of interferon signalling to avoid host immune response while VP40, the viral matrix protein is responsible for the viral assembly and budding as well as virus structure and stability (Booth et al. 2013; Olejnik et al. 2011). VP30 and VP40 were also found to be suppressors of RNA silencing beside VP35 (Fabozzi et al. 2011).

Among all of Ebola's protein, the matrix protein VP40 is considered as a promising drug target as it can induce virus-like particles (VLPs) formation even when expressed alone (Jasenosky et al. 2001). Besides, each different conformation of this protein reflects its different role throughout the Ebola life cycle. The monomeric form of VP40 serves as the building block for higher configuration of the VP40 (Adu-Gyamfi et al. 2012). Meanwhile, VP40 dimer and hexamer were shown to be associated with membrane interaction especially negatively charged lipidlike phosphatidylserine (PS) and phosphatidylinositol 4,5-bisphosphate ( $\mathrm{PIP}_{2}$ ), through its cationic patch in the C-terminal domain (Adu-Gyamfi et al. 2015; Del Vecchio et al. 2018; Gc et al. 2017; Johnson et al. 2016). VP40 also exist in octameric ring form and associates with the RNA binding activity through its N-terminal domain (GomisRüth et al. 2003; Ruigrok et al. 2000)

VP40-RNA binding activity plays an important role during its life cycle. Two amino acid residues namely Arg134 and Phe125 were shown to be the key residues involved in the RNA binding activity (Hoenen et al. 2005) (Figure 1). The mutation on these residues affects the RNA-binding process where mutation of Phe125 into Ala decreased RNA binding activity, meanwhile mutation of
Arg134 to Ala abolished the RNA binding activity as well as the formation of VP40 octamer (Hoenen et al. 2005). This RNA binding activity is crucial in viral transcription regulation as VP40 in ring form can recapitulate the transcription control function thus plays a significant role in Ebola life cycle especially in the early stage of infection (Bornholdt et al. 2013). Therefore, this RNA binding site serves as a potential drug target to interrupt the Ebola life cycle.

To date, no FDA-licensed drug is available to solve this problem and most of the potential drugs to treat the disease are yet to be used in human clinical trials (Yuan 2015). From the 2014-2016 outbreak, the calling for further research on understanding Ebola life cycle is more urgent than before. Even though the outbreak has mainly occurred in West Africa, current mobility in term of transportation might spread the disease further from its origin (Gonzalez et al. 2018). The situation can be worsened in the future due to the increase in human population which eases the transmission of disease through human to human transmission. Therefore, this study focuses on developing a potential drug for EVD by targeting the RNA binding site. Several computational studies have been carried out to find the potential VP40 inhibitors at the RNA binding site. For instance, a compound with ID ASN03576800 from Asinex database was identified by Tamilvanan and Hopper (2013) as a potential lead compound to inhibit VP40-RNA binding activity. Meanwhile, six potential compounds were identified by Raj and Varadwaj (2016) by screening flavonoid compounds from Timtec library. On the other hand, two compounds namely emodin-8-betaD-glucoside and tonkinochromane_G from TCMD were reported by Karthick et al. (2016) as potential VP40-RNA inhibitors. Recently, several candidates of natural herbal ligands namely Mahanine, Mahanimbine and Gumnosine were also found to have favourable interaction with VP40 (Setlur et al. 2017).

In total, 42 compounds have been reported to potentially block the VP40-RNA binding activity. However, all these previous studies only focused on in silico and none proceeded any further either in vivo and

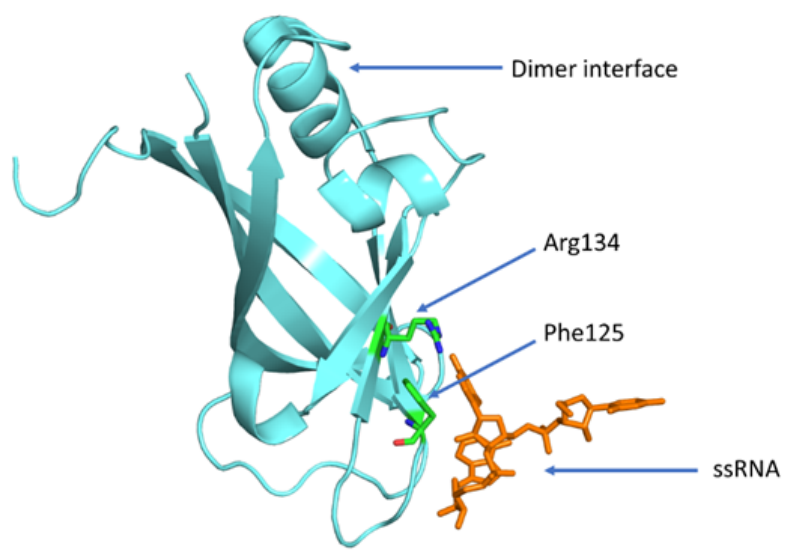

FIGURE 1. Truncated VP40 monomer structure with its important residues (Arg134 and Phe125) that involve in binding of ssRNA 
in vitro. Besides, all these studies mainly relied on screening compounds from various databases without any specific scaffold to suit the RNA binding site. Thus, this study was conducted to find and optimize the potential new ligands based on previously studied compounds for better inhibition at the RNA binding site. By considering all 42 previous studied compounds as starting template, both virtual screening method; ligandbased and structure-based through similarity search of compounds of similar scaffold in ZINC database were utilized in this study. The results presented in this study provide insights into the potential compounds that can block VP40-RNA binding activity.

\section{METHODS}

\section{PROTEIN PREPARATION}

The crystal structure of VP40 model was taken from Protein Data Bank (PDB) [PDB Entry: 1H2C]. The protein was cleaned by removing all other molecules in the complex including water atoms in the PDB file. The RNA binding site for docking simulation was predicted using COACH (Yang et al. 2013a, 2013b) accounting the important residues for RNA-binding activity, Arg134 and Phe125. Six residues were predicted to be in the RNA binding site namely Thr123, Phe125, Gly126, Lys127, Arg134, and Tyr171.

\section{LIGANDS PREPARATION AND MOLECULAR DOCKING OF PREVIOUSLY STUDIED LIGANDS}

A total of 42 ligands that were previously studied against RNA binding site of the VP40 protein have been identified from literatures (Abazari et al. 2015; Karthick et al. 2016; M Alam El-Din et al. 2016; Mirza \& Ikram 2016; Raj \& Varadwaj 2016; Setlur et al. 2017; Shah et al. 2015; Tamilvanan \& Hopper 2013). The compounds were labelled as L-1 till L-42. Since the compounds were previously docked using different software, we performed a set of docking simulations using a single software, AutoDock Vina version 1.1.2 (Trott \& Olson 2009). This software was chosen in this study as it provides faster calculation to pose the compound at the binding site as well as predicts the compound's binding mode more accurately (Trott \& Olson 2009). Furthermore, a comparison between several docking tools showed that AutoDock Vina has quite similar performance as Glide 6.6 and DOCK 6.5 but perform better than AutoDock 4 (Castro-Alvarez et al. 2017). Polar hydrogens were added to both protein and ligands while non-polar hydrogens were merged with the structure. Then, Kollman charges were added to the protein and ligands. The grid box was set to be $14.25 \times 20.25 \times 21$ with $1 \AA$ distance spacing. The grid centre was set to be 1.641, 14.662 and 28.551 for $\mathrm{x}, \mathrm{y}$ and $\mathrm{z}$ value, respectively. The maximum number of binding modes was set at 10 while the default exhaustiveness value was used during the simulation. Top ten ligands with the lowest binding energy were selected to serve as a template for ligand-based virtual screening in the next step.

\section{LIGAND-BASED VIRTUAL SCREENING}

Ligand-based virtual screening was carried out to screen compounds from ZINC database that have similar scaffold to the templates. The virtual screening was carried out using USRCAT (Schreyer \& Blundell 2012), an extension of USR at the USR-VS server (Li et al. 2016). The top ten ligands with preferred orientation and low binding energy at the RNA binding site from the first stage molecular docking was used as a template for the screening. Only 20 similar structures from the screening, ranked according to the USRCAT score for each template were taken for the next screening step resulting in a total of 200 new ligands. The new ligands were labelled as Q-1 till Q-200.

\section{MOLECULAR DOCKING OF NEW LIGANDS FROM SIMILARITY SEARCH}

All 200 ligands were docked at the predicted RNA binding site using Autodock vina version 1.1.2. (Trott \& Olson 2009). The compounds were ranked according to the order of binding energy, from the lowest to the highest as well as accounting the orientation of the ligand at the RNA binding site. Top 10 compounds that have better binding energy than the previously studied ligands were selected for the next step.

\section{LIGANDS ADME ANALYSIS}

The ADME properties of the top 10 compounds from structure-based virtual screening were predicted using SwissADME (Daina et al. 2017). The bioavailability radar to assess the drug-likeness of a compound based on six parameters; lipophilicity, size, polarity, solubility, flexibility and saturation was considered to select the best ligand. The compounds also being assessed for Lipinski's (Lipinski et al. 1997), Ghose's (Ghose et al. 1999), Veber's (Veber et al. 2002), Egan's (Egan et al. 2000) and Muegge's (Muegge et al. 2001) rules violation.

\section{RESULTS AND DISCUSSION}

\section{MOLECULAR DOCKING OF PREVIOUSLY STUDIED LIGANDS}

All 42 reported compounds in the literature that were previously investigated and targeted against VP40-RNA binding activity (Table 1) were docked again at the binding site using AutoDock Vina. Table 1 shows the top 10 out of 42 compounds according to its binding energy as well as residues involved in the binding interactions. All ten compounds displayed close contact with Phe125 and Arg134, the two important residues in mediating the VP40RNA binding activity (Gomis-Rüth et al. 2003; Hoenen et al. 2005). L-38 has the best binding energy of $-6.7 \mathrm{kcal} /$ mol and formed three H-bonds with residues Thr123, 
His 124 and Gly126 followed by L-21 (-6.5 kcal/mol) which also formed three H-bonds with the protein, one with Arg134 and two with Phe172. The ten compounds were then used as templates for ligand-based virtual screening in USR-CAT server to find compounds with similar scaffold as described in Methods. 200 new compounds were obtained based on the similarity score from virtual screening process and proceed for the next docking stage.

\section{MOLECULAR DOCKING OF NEW LIGANDS FROM} SIMILARITY SEARCH

A structure-based virtual screening of 200 compounds against RNA binding site was carried out and the ligands were ranked based on binding energy and preferred orientation at the binding site. From the simulations, 10 compounds were identified to give lower binding energy than the previous docking stage $(-6.7 \mathrm{kcal} / \mathrm{mol})$ and closely interacted with the RNA binding residues (Table 2). Q-96 has the lowest binding energy of $-7.5 \mathrm{kcal} / \mathrm{mol}$ and formed one H-bond with Arg134. Q-83 has the most H-bonds formed with the RNA binding residues namely Gly126 and Arg 134. We observed that all ten compounds interacted with Phe125 and Arg134 and with three other residues namely His124, Gln170 and Tyr171.

From the docking results, we found that the top 10 compounds are the results of ligand-based virtual screening from L-38, the top ligands from the first molecular docking stage. These 10 compounds can further be divided into two similar scaffold groups where Q-94, Q-97, Q-98 and Q-99 are grouped into a piperidine-based scaffold group containing benzene, oxadiazole, piperidine and carboxamide chain while Q-96, Q-93, Q-82, Q-83, Q-88 and Q-100 are grouped into pyridine-based scaffold that contains two benzene rings (one as benzamide and another as phenyl), triazole and pyridine except for Q-83 which has an oxadiazole ring instead of triazole. L-38 also has similar scaffold as pyridine-based group with $\mathrm{S}$ atom acting as the bridge to connect the two rings from each side into a single structure but having different chemical constituents at the ring of the structure (Figure 2 ). In general, all ten compounds have benzene in their structure as benzene is the most common ring listed in drug database followed by pyridine and piperidine (Taylor et al. 2014).

\section{LIGANDS ADME ANALYSIS}

The ADME properties of the potential ligands were computationally determined using SwissADME. From the result generated in SwissADME server, we found that all ten compounds did not violate the Lipinski's rule of five indicated that they have good drug-likeness properties. Also, we looked for any drug-likeness violations according to the other modified rules (Table 3) and found that Q-83 violates one Egan's rules by having TPSA value greater than 131.6 while Q-88 does not meet two Ghose's rule with a molecular weight exceeding $480 \mathrm{~g} / \mathrm{mol}$ and molar refractivity above 130. Meanwhile, Q-99 violates one Ghose's rule. All ligands gave an average bioavailability score of 0.55 .

Even though some of the ligands violated few druglikeness rules, all the compounds gave good lipophilicity properties with the consensus Log P value between $\sim 2.2$ and 3.4 (Table 4). According to Lipinski et al. (1997), log $\mathrm{P}$ should not exceed 5, as a desirable lipophilicity range for a compound to reach Phase II clinical trials. It is also noted that compounds with $\log \mathrm{P}<4$ and molecular weight below $400 \mathrm{~g} / \mathrm{mol}$ have better ADMET properties (Gleeson 2008). Furthermore, compounds with high lipophilicity (> 5) usually lead to rapid metabolic turnover (Waterbeemd

TABLE 1. Top docking result of previously reported compounds. Bolded residues are important residues in RNA binding activity

\begin{tabular}{lcccl}
\hline Ligands & Binding energy $(\mathrm{kcal} / \mathrm{mol})$ & No of H-bonds & H-bond residues & \multicolumn{1}{c}{ Interacting residues } \\
\hline L-38 & -6.7 & 3 & Thr123, His124, Gly126 & $\begin{array}{l}\text { Thr123, His124, Phe125, Gly126, Lys127, } \\
\text { Ala128, Arg134, Gln170, Tyr171 }\end{array}$ \\
L-21 & -6.5 & 3 & Arg134, Phe172(2) & $\begin{array}{l}\text { Thr123, His124, Phe125, Arg134, Tyr171, } \\
\text { Phe172, Thr173 }\end{array}$ \\
L-6 & -6.4 & - & - & $\begin{array}{l}\text { Phe125, Arg134, Tyr171, Phe172, Thr173 } \\
\text { Phe125, Gly126, Arg134, Tyr171 }\end{array}$ \\
L-1 & -6.3 & 1 & Arg134 & Thr123, Phe125, Arg134, Gln170, Tyr171 \\
L-3 & -6.3 & 1 & Arg134 & Thr123, His124, Phe125, Gly126, Ala128, \\
L-32 & -6.3 & 1 & Arg134 & Arg134, Gln170, Tyr171 \\
L-4 & -6.3 & 3 & Gly126, Ala128, Arg134 & $\begin{array}{l}\text { Thr123, His124, Phe125, Gly126, Lys127, } \\
\text { Ala128, Arg134, Gln170, Tyr171 }\end{array}$ \\
L-10 & -6.2 & 2 & Arg134, Thr173 & Thr123, His124, Phe125, Arg134, Tyr171, \\
& & & Thr173 & Thr123, Phe125, Gly126, Arg134, Gln170, \\
L-22 & -6.2 & 1 & Arg134 & Tyr171 \\
\hline
\end{tabular}


TABLE 2. Top compounds from virtual screening and molecular docking process. Bolded residues are important residues in RNA binding activity

\begin{tabular}{|c|c|c|c|c|c|}
\hline Ligand & ZINC ID & Binding energy $(\mathrm{kcal} / \mathrm{mol})$ & No of H-bonds & H-bond residues & Interacting residues \\
\hline Q-96 & 1338855 & -7.5 & 1 & Arg134 & $\begin{array}{l}\text { Thr123, His124, Phe125, Gly126, } \\
\text { Ala128, Arg134, Gln170, Tyr171 }\end{array}$ \\
\hline Q-82 & 1338833 & -7.4 & - & - & $\begin{array}{l}\text { Thr123, His124, Phe125, Ala128, } \\
\text { Pro131, Arg134, Gln170, Tyr171 }\end{array}$ \\
\hline Q-97 & 40958549 & -7.3 & 2 & Gln170, Tyr171 & $\begin{array}{l}\text { Thr123, His124, Phe125, Gly126, } \\
\text { Ala128, Arg134, Gln170, Tyr171 }\end{array}$ \\
\hline Q-83 & 59213111 & -7.2 & 3 & $\begin{array}{l}\text { Gly126, Arg134 } \\
\text { (2) }\end{array}$ & $\begin{array}{l}\text { Thr123, His124, Phe125, Gly126, } \\
\text { Arg134, Gln170, Tyr171 }\end{array}$ \\
\hline Q-93 & 1338837 & -7.2 & 1 & Arg134 & $\begin{array}{l}\text { Thr123, His124, Phe125, Gly126, } \\
\text { Ala128, Arg134, Gln170, Tyr171 }\end{array}$ \\
\hline Q-88 & 1342431 & -7.1 & - & - & $\begin{array}{l}\text { Thr123, His124, Phe125, Gly126, } \\
\text { Ala128, Pro131, Arg134, Gln170, } \\
\text { Tyr171 }\end{array}$ \\
\hline Q-94 & 40930748 & -6.9 & 1 & His 124 & $\begin{array}{l}\text { Thr123, His124, Phe125, Gly126, } \\
\text { Ala128, Arg134, Gln170, Tyr171 }\end{array}$ \\
\hline Q-98 & 41279804 & -6.9 & 2 & Arg134, Tyr171 & $\begin{array}{l}\text { His124, Phe125, Gly126, Arg134, } \\
\text { Gln170, Tyr171 }\end{array}$ \\
\hline Q-99 & 41279972 & -6.9 & 1 & Arg134 & $\begin{array}{l}\text { Thr123, His124, Phe125, Gly126, } \\
\text { Ala128, Arg134, Gln170, Tyr171 }\end{array}$ \\
\hline Q-100 & 1342435 & -6.8 & - & - & $\begin{array}{l}\text { His124, Phe125, Ala128, Pro131, } \\
\text { Arg134, Gln170, Tyr171 }\end{array}$ \\
\hline
\end{tabular}

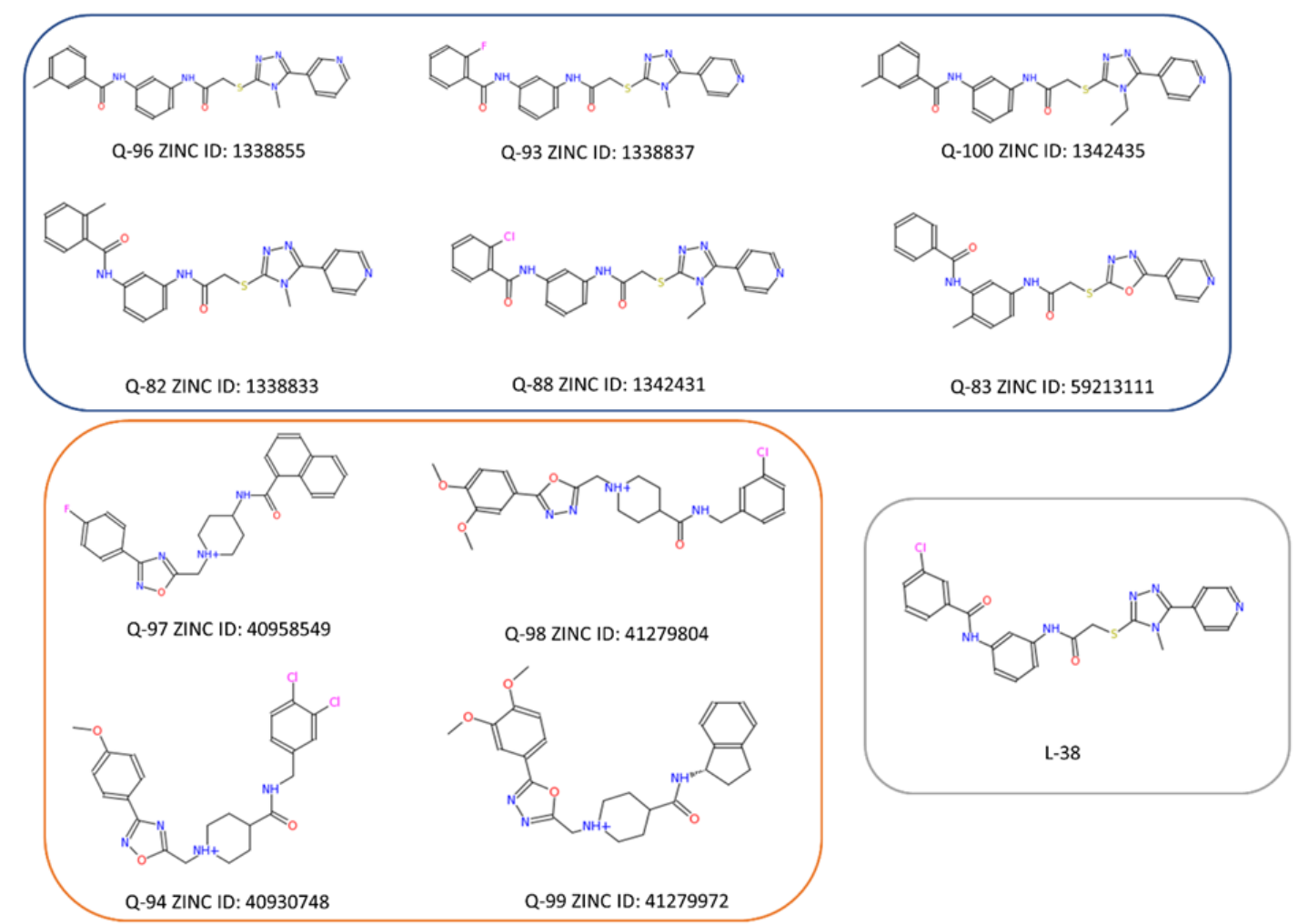

FIGURE 2. Chemical structure of the top ten compounds and L-38. The pyridine group (blue box) consists of Q-96, Q-93, Q-82, Q-83, Q-88 and Q-100 that have two benzene rings, triazole and pyridine except for Q-83 which has an oxadiazole ring instead of triazole. The piperidine group (orange box) consists of Q-94, Q-97, Q-98 and Q-99 with chemical structure containing benzene, oxadiazole, piperidine and carboxamide rings. L-38 has similar scaffold of chemical structure to the pyridine group 
TABLE 3. Drug likeness violations and bioavailability score for each ligand. (MW= Molecular weight, MR= Molar refractivity, TPSA= Topological polar surface area)

\begin{tabular}{lcccccc}
\hline Ligands & Lipinski violations & Ghose violations & Veber violations & Egan violations & $\begin{array}{c}\text { Muegge } \\
\text { violations }\end{array}$ & $\begin{array}{c}\text { Bioavailability } \\
\text { Score }\end{array}$ \\
\hline Q-96 & 0 & 0 & 0 & 0 & 0 & 0.55 \\
Q-82 & 0 & 0 & 0 & 0 & 0 & 0.55 \\
Q-97 & 0 & 0 & 0 & 0 & 0 & 0.55 \\
Q-83 & 0 & 0 & 0 & 1 (TPSA $>131.6)$ & 0 & 0.55 \\
Q-93 & 0 & 0 & 0 & 0 & 0 & 0.55 \\
Q-88 & 0 & $2(\mathrm{MW}>480, \mathrm{MR}>130)$ & 0 & 0 & 0 & 0.55 \\
Q-94 & 0 & 0 & 0 & 0 & 0 & 0.55 \\
Q-98 & 0 & 0 & 0 & 0 & 0 & 0.55 \\
Q-99 & 0 & $1(\mathrm{MR}>130)$ & 0 & 0 & 0 & 0.55 \\
Q-100 & 0 & 1 & 0 & & 0 & 0.55 \\
\hline
\end{tabular}

TABLE 4. ADME properties for each ligand

\begin{tabular}{lccccccc}
\hline Ligands & ZINC ID & Consensus Log P & ESOL Log S & ESOL Class & GI absorption & PAINS alerts & Brenk alerts \\
\hline Q-96 & 1338855 & 2.99 & -4.48 & Moderately soluble & High & 0 \\
Q-82 & 1338833 & 2.93 & -4.48 & Moderately soluble & High & 0 \\
Q-97 & 40958549 & 3.04 & -5.47 & Moderately soluble & High & 0 & 0 \\
Q-83 & 59213111 & 3.16 & -4.61 & Moderately soluble & Low & 0 & 0 \\
Q-93 & 1338837 & 2.85 & -4.33 & Moderately soluble & Low & 0 & 0 \\
Q-88 & 1342431 & 3.39 & -4.96 & Moderately soluble & Low & 0 \\
Q-94 & 40930748 & 2.98 & -5.29 & Moderately soluble & High & 0 \\
Q-98 & 41279804 & 2.44 & -4.52 & Moderately soluble & High & 0 \\
Q-99 & 41279972 & 2.23 & -4.4 & Moderately soluble & High & 0 \\
Q-100 & 1342435 & 3.28 & -4.67 & Moderately soluble & Low & 0 \\
L-38 & - & 3.11 & -4.77 & Moderately soluble & Low & 0 \\
\hline
\end{tabular}

et al. 2001), poor absorption and lower solubility (Lipinski et al. 1997) while low lipophilicity compounds generally have poor ADMET properties (Arnott \& Planey 2012).

Meanwhile, water-solubility properties prediction based on ESOL model through the Log $\mathrm{S}$ calculation showed that all compounds exhibited moderate solubility (Table 4). This is understood as all the compounds have molecular weight more than $400 \mathrm{~g} / \mathrm{mol}$ and lipophilicity $(\log \mathrm{P})$ in the range of 2.2 to 3.4 as an increase in molecular weight and lipophilicity will decrease the water solubility. However, having poorly soluble compounds in designing drug is not a major problem as several strategies have been employed to overcome this problem (Lipinski 2002). This includes the use of complexing drugs with cyclodextrins (Vyas et al. 2008), ionized drug through salt formation (Serajuddin 2007), conjugation to dendrimers (Gupta et al. 2006) and the use of co-solvents (Akers 2002; Strickley 2004).

As tabulated in Table 4, some of the compounds have high GI absorption prediction (Q-96, Q-82, Q-97, Q-94, Q-98 and Q-99) while some have low GI absorption prediction (Q-83, Q-93, Q-88, Q-100 and L-38). GI absorption is an important parameter in the drug delivery process. Poor GI absorption will have caused low drug level absorbed from the gut into the bloodstream thus will affect the overall oral bioavailability (Clark 2011). Interestingly all ligands did not have PAINS (Baell \& Holloway 2010) or Brenk (Brenk et al. 2008) alerts indicates that all ligands do not have any unfavourable moieties or fragments in their chemical structure.

\section{CONCLUSION}

We have used computational approaches to screen potential compounds that can be targeted against Ebola VP40-RNA binding site. In this work, we found several compounds with good binding energy at the RNA binding site with satisfying ADME properties. Q-96 (ZINC ID: 1338855) is the best binding ligand with no major ADME problem. Other ligands namely Q-82, Q-97, Q-94 and Q-98 could also serve as potential inhibitors to inhibit VP40-RNA activity. This study produces a set of potential compounds, in which its inhibitory activity can be further validated via an experimental approach such as enzymatic assay. A more 
detail analysis at the molecular level on the protein-ligand interaction such as molecular dynamics simulation should be done on the potential compounds to monitor the stability of the VP40-ligand complexes. Besides, more accurate binding energy calculation like MM-PBSA can be carried out to further justify the ligands-protein interaction and give more insights on the suitable chemical scaffold that suit the RNA binding site.

\section{ACKNOWLEDGEMENTS}

This work was supported by the Ministry of Higher Education (MOHE), Malaysia and International Islamic University, Malaysia under grant FRGS15-207-0448, FRGS15-208-0449 and PRIGS18-062-0062.

\section{REFERENCES}

Abazari, D., Moghtadaei, M., Behvarmanesh, A., Ghannadi, B., Aghaei, M., Behruznia, M. \& Rigi, G. 2015. Molecular docking based screening of predicted potential inhibitors for VP40 from Ebola virus. Bioinformation 11: 243-247.

Adu-Gyamfi, E., Digman, M.A., Gratton, E. \& Stahelin, R.V. 2012. Investigation of Ebola VP40 assembly and oligomerization in live cells using number and brightness analysis. Biophys. J. 102: 2517-2525.

Adu-Gyamfi, E., Johnson, K.A., Fraser, M.E., Scott, J.L., Soni, S.P., Jones, K.R., Digman, M.A., Gratton, E., Tessier, C.R. \& Stahelin, R.V. 2015. Host cell plasma membrane phosphatidylserine regulates the assembly and budding of Ebola virus. J. Virol. 89: 9440-9453.

Akers, M.J. 2002. Excipient-drug interactions in parenteral formulations. J. Pharm. Sci. 91: 2283-2300.

Arnott, J.A. \& Planey, S.L. 2012. The influence of lipophilicity in drug discovery and design. Expert Opin. Drug Discov. 7: 909-921.

Baell, J.B. \& Holloway, G.A. 2010. New substructure filters for removal of pan assay interference compounds (PAINS) from screening libraries and for their exclusion in bioassays. J. Med. Chem. 53: 2719-2740.

Booth, T.F., Rabb, M.J. \& Beniac, D.R. 2013. How do filovirus filaments bend without breaking? Trends Microbiol. 21: 583-593.

Bornholdt, Z.A., Noda, T., Abelson, D.M., Halfmann, P., Wood, M.R., Kawaoka, Y. \& Saphire, E.O. 2013. Structural rearrangement of Ebola virus VP40 begets multiple functions in the virus life cycle. Cell 154: 763-774.

Brenk, R., Schipani, A., James, D., Krasowski, A., Gilbert, I.H., Frearson, J. \& Wyatt, P.G. 2008. Lessons learnt from assembling screening libraries for drug discovery for neglected diseases. ChemMedChem. 3: 435-444.

Castro-Alvarez, A., Costa, A.M. \& Vilarrasa, J. 2017. The performance of several docking programs at reproducing protein-macrolide-like crystal structures. Molecules 22: $1-14$.

Clark, D.E. 2011. What has polar surface area ever done for drug discovery? Future Med. Chem. 3: 469-484.

Daina, A., Michielin, O. \& Zoete, V. 2017. SwissADME: A free web tool to evaluate pharmacokinetics, drug-likeness and medicinal chemistry friendliness of small molecules. Sci. Rep. 7: 42717

Del Vecchio, K., Frick, C.T., Gc, J.B., Oda, S., Gerstman, B.S., Saphire, E.O., Chapagain, P.P. \& Stahelin, R.V. 2018. A cationic, C-terminal patch and structural rearrangements in Ebola virus matrix VP40 protein control its interactions with phosphatidyserine. J. Biol. Chem. 293: 3335-3349.

Egan, W.J., Merz, K.M. \& Baldwin, J.J. 2000. Prediction of drug absorption using multivariate statistics. J. Med. Chem. 43: 3867-3877.

Fabozzi, G., Nabel, C.S., Dolan, M.A. \& Sullivan, N.J. 2011. Ebola virus proteins suppress the effects of small interfering RNA by direct interaction with the mammalian RNA interference pathway. J. Virol. 85: 2512-2523.

Feldmann, H. \& Geisbert, T.W. 2011. Ebola haemorrhagic fever. Lancet. 377: 849-862.

Gc, J.B., Gerstman, B.S. \& Chapagain, P.P. 2017. Membrane association and localization dynamics of the Ebola virus matrix protein VP40. Biochim. Biophys. Acta - Biomembr. 1859: 2012-2020.

Ghose, A.K., Viswanadhan, V.N. \& Wendoloski, J.J. 1999. A knowledge-based approach in designing combinatorial or medicinal chemistry libraries for drug discovery. 1. A qualitative and quantitative characterization of known drug databases. J. Comb. Chem. 1: 55-68.

Gleeson, M.P. 2008. Generation of a set of simple, interpretable ADMET rules of thumb. J. Med. Chem. 51 817-834.

Gomis-Rüth, F.X., Dessen, A., Timmins, J., Bracher, A., Kolesnikowa, L., Becker, S., Klenk, H.D. \& Weissenhorn, W. 2003. The matrix protein VP40 from Ebola virus octamerizes into pore-like structures with specific RNA binding properties. Structure 11: 423-433.

Gonzalez, J.P., Wauquier, N. \& Vincent, T. 2018. Revisiting Ebola, a quiet river in the heart of Africa. Med. Sante Trop. 28: $12-17$.

Gupta, U., Agashe, H.B., Asthana, A. \& Jain, N.K. 2006. Dendrimers: Novel polymeric nanoarchitectures for solubility enhancement. Biomacromolecules 7: 649-658.

Hoenen, T., Volchkov, V., Kolesnikova, L., Mittler, E., Timmins, J., Ottmann, M., Reynard, O., Becker, S. \& Weissenhorn, W. 2005. VP40 octamers are essential for Ebola virus replication. J. Virol. 79: 1898-1905.

Jasenosky, L.D., Neumann, G., Lukashevich, I. \& Kawaoka, Y. 2001. Ebola virus VP40-induced particle formation and association with the lipid bilayer. J. Virol. 75: 5205-5214.

Johnson, K.A., Taghon, G.J.F., Scott, J.L. \& Stahelin, R.V. 2016. The Ebola virus matrix protein, VP40, requires phosphatidylinositol 4,5-bisphosphate $(\mathrm{PI}(4,5) \mathrm{P} 2)$ for extensive oligomerization at the plasma membrane and viral egress. Sci. Rep. 6: 19125.

Karthick, V., Nagasundaram, N., Doss, C.G.P., Chakraborty, C., Siva, R., Lu, A., Zhang, G. \& Zhu, H. 2016. Virtual screening of the inhibitors targeting at the viral protein 40 of Ebola virus. Infect. Dis. Poverty 5: 12. Doi: 10.1186/ s40249-016-0105-1.

Li, H., Leung, K.S., Wong, M.H. \& Ballester, P.J. 2016. USR-VS: A web server for large-scale prospective virtual screening using ultrafast shape recognition techniques. Nucleic Acids Res. 44: W436-W441.

Lipinski, C. 2002. Poor aqueous solubility - An industry wide problem in drug discovery. Am. Pharm. Rev. 5: 82-85.

Lipinski, C.A., Lombardo, F., Dominy, B.W. \& Feeney, P.J. 1997. Experimental and computational approaches to estimate solubility and permeability in drug discovery and development settings. Adv. Drug Deliv. Rev. 46: 3-26.

M Alam El-Din, H., A Loutfy, S., Fathy, N., H Elberry, M., M Mayla, A., Kassem, S. \& Naqvi, A. 2016. Molecular 
docking based screening of compounds against VP40 from Ebola virus. Bioinformation 12: 192-196.

Martin, B., Canard, B. \& Decroly, E. 2017. Filovirus proteins for antiviral drug discovery: Structure/function bases of the replication cycle. Antiviral Res. 141: 48-61.

Martin, B., Hoenen, T., Canard, B. \& Decroly, E. 2016. Filovirus proteins for antiviral drug discovery: A structure/function analysis of surface glycoproteins and virus entry. Antiviral Res. 135: 1-14.

Mirza, M.U. \& Ikram, N. 2016. Integrated computational approach for virtual hit identification against Ebola viral proteins VP35 and VP40. Int. J. Mol. Sci. 17(11): 1748.

Muegge, I., Heald, S.L. \& Brittelli, D. 2001. Simple selection criteria for drug-like chemical matter. J. Med. Chem. 44: 1841-1846

Olejnik, J., Ryabchikova, E., Corley, R.B. \& Mühlberger, E. 2011. Intracellular events and cell fate in filovirus infection. Viruses 3: 1501-1531.

Raj, U. \& Varadwaj, P.K. 2016. Flavonoids as multi-target inhibitors for proteins associated with Ebola virus: In silico discovery using virtual screening and molecular docking studies. Interdiscip. Sci. Comput. Life Sci. 8: 132-141.

Ruigrok, R.W., Schoehn, G., Dessen, A., Forest, E., Volchkov, V., Dolnik, O., Klenk, H.D. \& Weissenhorn, W. 2000. Structural characterization and membrane binding properties of the matrix protein VP40 of Ebola virus. J. Mol. Biol. 300: 103-112.

Schreyer, A.M. \& Blundell, T. 2012. USRCAT: Real-time ultrafast shape recognition with pharmacophoric constraints. J. Cheminform. 4: 27.

Serajuddin, A.T.M. 2007. Salt formation to improve drug solubility. Adv. Drug Deliv. Rev. 59: 603-616.

Setlur, A.S., Naik, S.Y. \& Skariyachan, S. 2017. Herbal lead as ideal bioactive compounds against probable drug targets of Ebola virus in comparison with known chemical analogue: A computational drug discovery perspective. Interdiscip. Sci. Comput. Life Sci. 9: 254-277.

Shah, R., Panda, P.K., Patel, P., Mumbai, N., Farm, A. \& Road, G.D. 2015. Pharmacophore based virtual screening and molecular docking studies of inherited compounds against Ebola virus receptop proteins. World J. Pharm. Pharm. Sci. 4: $1268-1282$.

Strickley, R.G. 2004. Solubilizing excipients in oral and injectable formulations. Pharm. Res. 21: 201-230.

Tamilvanan, T. \& Hopper, W. 2013. High-throughput virtual screening and docking studies of matrix protein VP40 of Ebola virus. Bioinformation 9: 286-292.

Taylor, R.D., Maccoss, M. \& Lawson, A.D.G. 2014. Rings in drugs. J. Med. Chem. 57: 5845-5859.

Trott, O. \& Olson, A.J. 2009. Software news and update AutoDock Vina: Improving the speed and accuracy of docking with a new scoring function, efficient optimization, and multithreading. J. Comput. Chem. 31: 455-461.
Van de Waterbeemd, H., Smith, D.A., Beaumont, K. \& Walker, D.K. 2001. Property-based design: Optimization of drug absorption and pharmacokinetics. J. Med. Chem. 44: 13131333.

Veber, D.F., Johnson, S.R., Cheng, H., Smith, B.R., Ward, K.W. \& Kopple, K.D. 2002. Molecular properties that influence the oral bioavailability of drug candidates. J. Med. Chem. 45: 2615-2623.

Vyas, A., Saraf, Shailendra. \& Saraf, Swarnlata. 2008. Cyclodextrin based novel drug delivery systems. J. Incl. Phenom. Macrocycl. Chem. 62: 23-42.

WHO | Ebola Situation Reports: Democratic Republic of the Congo, 2019.

WHO | Ebola Virus Disease 2017.

Yang, J., Roy, A. \& Zhang, Y. 2013a. Protein-ligand binding site recognition using complementary binding-specific substructure comparison and sequence profile alignment. Bioinformatics 29: 2588-2595.

Yang, J., Roy, A. \& Zhang, Y. 2013b. BioLiP: A semi-manually curated database for biologically relevant ligand-protein interactions. Nucleic Acids Res. 41: 1096-1103.

Yuan, S. 2015. Possible FDA-approved drugs to treat Ebola virus infection. Infect. Dis. Poverty 4: 23.

Mohamad Ariff Mohamad Yussoff, Azzmer Azzar Abd Hamid \& Khairul Bariyyah Abd Halim*

Department of Biotechnology

Kulliyyah of Science

International Islamic University Malaysia

25200 Kuantan, Pahang Darul Makmur

Malaysia

Shafida Abd Hamid

Department of Chemistry

Kulliyyah of Science

International Islamic University Malaysia

25200 Kuantan, Pahang Darul Makmur

Malaysia

Azzmer Azzar Abd Hamid \& Khairul Bariyyah Abd Halim*

Research Unit for Bioinformatics and Computational Biology

Kulliyyah of Science

International Islamic University Malaysia

25200 Kuantan, Pahang Darul Makmur

Malaysia

*Corresponding author; email: kbariyyah@iium.edu.my

Received: 1 August 2019

Accepted: 5 December 2019 